\title{
Social determinants of hospitalizations for ambulatory care sensitive conditions in Guarulhos, São Paulo*
}

\author{
DETERMINANTES SOCIAIS DAS INTERNAÇÕES POR CONDIÇÕES SENSÍVEIS À \\ ATENÇÃO PRIMÁRIA EM GUARULHOS, SÃO PAULO
}

\section{LOS DETERMINANTES SOCIALES DE LAS HOSPITALIZACIONES POR CONDICIONES SENSIBLES A LAATENCIÓN PRIMARIA EN GUARULHOS, SÃO PAULO}

\author{
Maykon Diego Melo', Emiko Yoshikawa Egry²
}

\section{RESUMO}

Objetivo: Apresentar o panorama das Internações por Condições Sensíveis à Atenção Primária (ICSAP) no município de Guarulhos, SP, no período de 2008 a 2012. Método: Estudo ecológico, com dados secundários obtidos via Sistema de Informações Hospitalares, sustentado pela Teoria de Intervenção Práxica da Enfermagem em Saúde Coletiva. Empregou-se estatística descritiva para análise. Resultados: Observou-se que Guarulhos apresenta trajetória crescente nas internações por ICSAP (aumento de $20 \%$ ), sendo as causas mais frequentes a insuficiência cardíaca $(11,8 \%)$, as doenças cerebrovasculares $(10,6 \%)$ e a angina $(9,7 \%)$, com maior frequência na faixa etária $\geq 65$ anos, para ambos os sexos. Conclusão: Os resultados encontrados se assemelham a outros estudos brasileiros, porém sua análise deve extrapolar os limites biológicos e a oferta de recursos assistenciais, atentando para as determinações sociais do processo saúde-doença.

\section{DESCRITORES}

Hospitalização

Atenção Primária à Saúde

Qualidade da Assistência à Saúde

Avaliação em saúde

Enfermagem em saúde pública

\begin{abstract}
The study goals present an overview of Hospitalizations for Ambulatory Care Sensitive Conditions (ACSC) in Guarulhos, SP, from 2008 to 2012. This is an ecological study based on secondary data obtained from the Brazilian Hospital Information System, and supported by the Praxical Theory of Intervention of Collective Health Nursing. Applied descriptive statistics for analysis. It was observed that Guarulhos shows an upward trend in hospitalizations by ACSC ( $20 \%$ increase), the most frequent causes of heart failure $(11.8 \%)$, cerebrovascular disease (10.6\%) and angina (9.7\%), most frequently in the age group $\geq 65$ years old, for both sexes. The results are similar to other Brazilian studies, but their analysis should extrapolate the biological limits and the supply of healthcare resources, focusing on the social determinants of the health-disease process.
\end{abstract}

\author{
DESCRIPTORS \\ Hospitalization \\ Primary Health Care \\ Quality of Health Care \\ Health evaluation \\ Public health nursing
}

\section{RESUMEN}

El estudio tuvo como objetivo proporcionar una visión general de las Hospitalizaciones por Condiciones Sensibles a la Atención Primaria (ICSAP) en Guarulhos, SP, en el período 2008-2012. Se trata de un estudio ecológico a partir de datos secundarios obtenidos a través del Sistema de Información Hospitalaria, y apoyado por la Teoría de Intervención Práxica de la Enfermería en Salud Colectiva. Se aplicó la estadística descriptiva para el análisis. Se observó que Guarulhos muestra una tendencia al alza en las hospitalizaciones por ICSAP (aumento del $20 \%$ ), las causas más frecuentes de insuficiencia cardiaca $(11,8 \%)$, enfermedad cerebrovascular $(10,6 \%)$ y la angina $(9,7 \%)$, con mayor frecuencia en el grupo de edad $\geq 65$ años para ambos sexos. Los resultados son similares a otros estudios brasileños, pero su análisis debe extrapolar los límites biológicos y el suministro de los recursos sanitarios, centrándose en los determinantes sociales del proceso salud-enfermedad.

\author{
DESCRIPTORES \\ Hospitalización \\ Atención Primaria de Salud \\ Calidad de la Atención en Salud \\ Evaluación en salud \\ Enfermería en salud pública
}

* Extract from the dissertation “Internações por Condições Sensíveis à Atenção Primária em Guarulhos: um olhar da enfermagem em saúde coletiva”, School of Nursing, University of São Paulo, 2014. ${ }^{1}$ Master's degree in Sciences, School of Nursing, University of São Paulo, São Paulo, SP, Brazil. ${ }^{2}$ Full professor, Department of Nursing in Collective Health Care, School of Nursing, University of São Paulo, São Paulo, SP, Brazil. 


\section{INTRODUCTION}

Primary health care has had an effect on discussions about the organization of health care systems all over the world. Among the Latin American countries, the implementation of primary care was gradually achieved by social movements in the late 1960s, which fought against individual, curative and hospital-centered care, which was essentially associated with biological processes and met only the demands of the current economic system ${ }^{(1)}$.

Such reflections and changes in the health care system justified sanitary reform in Brazil. The concept of collective health began to take shape, representing the border between biological and social, and emerged as a new field for theory and practice, in opposition to public health ${ }^{(2)}$.

As it includes life conditions that are closely related to the forms of organization of society, collective health distinguishes the pathological profiles of the population and analyzes them from the social determinants process approach to heath-disease, a critical framework of political, social and cultural aspects based on Marxist concepts that go beyond the pluricausal notion responsible for disease and assimilates the illness process determined by the realistic dynamics of social reproduction ${ }^{(1)}$.

The Brazilian fight for acknowledgment of health as a social right was consolidated after the Federal Constitution of 1988 was promulgated and the Unified Health System (SUS, as per its acronym in Portuguese) was created, which presented in its health care policies the concept of basic care $(\mathrm{BC})$, instead of primary health care. Despite all the criticism, and even though they carry different ideological and conceptual contexts that range from functionalist and rational references to more progressive, with almost opposite meanings, the definitions of $\mathrm{BC}$ and $\mathrm{PHC}$ are used synonymously in Brazil( ${ }^{(3-4)}$.

Six years after the SUS was implemented, the Ministry of Health launched the Family Health Program (FHP) in 1994, which aimed to (re)conduct the organization of BC, following the precepts of $\mathrm{PHC}$, but adding policies of territoriality, longitudinality of care, intersectoriality, decentralization of management, prioritization of levels of care and social control in government health actions, promoting a care service oriented toward the needs of individuals.

With the expansion and success of the FHP in states and municipalities, the Ministry of Health reaffirmed the general principles for $\mathrm{BC}$ and validated the program as a national strategy in 2006, which became the Family Health Strategy (FHS), formalized by Resolution GM/MS number 648 , of March 28, which established the National Policy of Basic Care (NPBC), recently examined and reaffirmed ${ }^{(6)}$.

The number of municipalities and the population covered by the FHS has already exceeded 100 million, against only 1.1 million in 1994, at the beginning of the program $^{(7)}$. The FHS seeks a more rational use of the other levels of care and achieves favorable results regarding the evaluation made by users, managers and health professionals ${ }^{(8-9)}$.

In addition, its characterization as a model for basic care has a logic of organizing care in Health Care Networks ( $\mathrm{HCN})$. This reengineering aims to overcome health care system fragmentation, and consists of organizational arrangements, shaped actions and services in health that are integrated with different technological settings and missions in health, articulated in a complementary manner and with a territorial base ${ }^{(4,6)}$.

In order to indirectly assess the performance of the services provided by $\mathrm{PHC}$ and evaluate their quality through access and the capacity to solve problems, rates of hospitalizations for ambulatory care sensitive conditions (ACSC) were used. This measure was initially developed in the United States at the end of the 1980s, and has since been applied as an assessment and monitoring tool in $\mathrm{PHC}$, in areas of different sizes ${ }^{(9-14)}$.

Hospitalizations for ambulatory care sensitive conditions are interventions that could have been avoided if basic resources were used at the first level of care, as long as they were efficient and of good quality. ACSC include chronic diseases such as diabetes, asthma, and hypertension and acute diseases like pneumonia and other infections. Therefore, interventions made after adequate access and resolution in $\mathrm{PHC}$ optimize the prevention of this kind of hospitalization.

On the international scene, different lists of diagnoses considered to be avoidable by utilization of PHC are chosen as performance markers for primary health care ${ }^{(10,15)}$. As for Brazil, a national list of ACSC was made by a group of researchers and managers of the SUS, following an American model, that was applied in Spanish studies and adapted to the Brazilian reality ${ }^{(8)}$. Since then, the Ministry of Health has described its use as an instrument for the assessment of primary care and/or of the hospital care level, and it can be used to assess the performance of the health care systems in the three spheres of public power ${ }^{(16)}$.

It is worth highlighting that some authors have found some associations in the results of ACSC when they considered variables related to gender (female), age group (children and the elderly), poor socioeconomic conditions and low incomes, demographic situation (rural areas), ethnic and racial differences (non-Latin and afro descendents $)^{(5,9-10,15)}$, as well as determinants such as worldview (idealist) and understanding of the health-disease process (pluricausal) by the players involved in the execution of health policies ${ }^{(17)}$.

Today we can affirm that the assessment of hospitalizations for ACSC is an essential tool for monitoring the performance of the care network and for assessing the quality of primary care in many countries, including Brazil. 
The goal of this study was to understand the reality in order to change it, and the objective was to create a profile of hospitalizations for ACSC recorded in the city of Guarulhos, the biggest non-capital Brazilian city, between 2008 and 2012.

The choice of Guarulhos is justified by the fact that it had as one of its goals for the 2010-2013 Municipal Health Plan a decrease of hospitalizations for basic care sensitive conditions, and the need to strengthen care management and health networks supervised by basic care was observed ${ }^{(18)}$. In that sense, the profile of hospitalizations for ACSC, analyzed from the point of view of collective health and the social determinants of the heath-disease process, supports managers in the decision-making process and guides their reflections on equitable policies concerning primary care and the guarantee of universal and complete care.

\section{METHOD}

This study has an ecological design that used secondary data to describe the rates of hospitalization for ambulatory care sensitive conditions in the municipality of Guarulhos, São Paulo, between 2008 and 2012.

Supported by the Praxical Theory of Intervention of Collective Health Nursing (PTICHN), this study used the first two steps of the method, which consist of bringing and interpreting the objective reality of a given phenomenon. Two conceptual categories were considered: collective health and social determinants of the healthdisease process, from the approach of historical and dialectical materialism, so as to understand the results of hospitalizations for $\operatorname{ACSC}^{(19)}$.

Guarulhos is located in the northeastern area of the metropolitan region of São Paulo (MRSP), and is one of its 39 municipalities. According to the Brazilian Institute of Geography and Statistics ${ }^{(20)}$, the municipality is the $8^{\text {th }}$ largest economy in Brazil and the $2^{\text {nd }}$ largest in the State of São Paulo. However, living conditions in the city show that Guarulhos is part of a group of municipalities that do not have good social indicators, despite having high levels of wealth ${ }^{(21)}$. The SUS from Guarulhos shows the need to integrate actions and services in health care in order to strengthen care management organized by BC, by focusing on chronic noncommunicable diseases (CNCDs) and on the consolidation of health care networks ${ }^{(18)}$.

Data on hospitalizations of residents of Guarulhos, based on the Brazilian list of hospitalizations for $\operatorname{ACSC}^{(16)}$, came from the hospital information system (SIH-SUS) between 2008 and 2012, whose source is the authorization of hospitalization (AIH). For data tabulation in the database, Tabwin software, version 3.5 was used, which was developed by the IT Department of the SUS (DATASUS). Statistical analysis was done in a Microsoft Excel spreadsheet, using the following variables of interest: year, age group and gender.

The rates of hospitalization for ACSC were calculated by the proportion between the total number of hospitalizations of Guarulhos residents and the total population living in the municipality during the year of study (according to the Brazilian Institute of Geography and Statistics) for a group of ten thousand inhabitants. The percentage variation was defined by the proportion of the difference between hospitalization rates (from the first and last year studied) and the hospitalization rate of the first year. The proportion of hospitalizations for ACSC in the total number of hospitalizations (not including labor) and the proportion of each sensitive diagnosis group in the total of hospitalizations for ACSC were also calculated.

The coverage of the chosen FHS corresponds to available electronic data on the Support of Strategic Management ${ }^{(7)}$ website. The report of establishments within the municipality was collected on the Internet through the $\mathrm{Na}$ tional Record of Health Establishments in 2014(CNESNet; http://cnes.datasus.gov.br).

This research did not involve any intervention with human beings. Secondary data collected for managerial purposes were used, which were available online in public databases.

\section{RESULTS}

Guarulhos has a hospital network made up of two state hospitals, three municipal hospitals, two philanthropic partners of the SUS, five private hospitals and one long-term state-run philanthropic institution.

Regarding primary care, there are 67 basic health units (UBS) managed by the Municipal Secretariat, which are divided into four care zones, of which 28 are regular units, 35 follow the model of family health and four are mixed (regular but with the strategy of the Community Health Agents Program [PACS]). The population covered by FHS teams reached 19.1\% in 2008, with poorer results in 2009 $(17.3 \%)$ and $2010(18.1 \%)$, then with a $12 \%$ increase in 2011 (21.5\%) and a slight decrease again in 2012 (21.3\%). As for the number of community agents between 2008 and 2012, it increased gradually, from 663 to 745 professionals, eventually covering 428,375 people last year $(12 \%$ increase), but it is still considered poor coverage.

Concerning the reengineering of the health care system, Guarulhos has only one health care network, labor and birth, which integrates actions and services oriented toward pregnant and breast-feeding women and children. The managers in health have been developing other theme networks (emergency care network, psychosocial network, and oncological care network, among others), but they face some challenges that make the expansion difficult. 
The hospitalizations of Guarulhos inhabitants totaled 332,435 between 2008 and 2012, of which 12\% were births; therefore, 293,788 were hospitalizations for other reasons (considered as normal pregnancy outcomes and influenced by the fertility rate) ${ }^{(13)}$. The hospitalizations for ACSC represent $16 \%$ of these hospitalizations $(47,703)$, followed by the average annual rate of 76 per 10,000 inhabitants. Between 2008 and 2010, an increase of 26\% was observed in hospitalizations for ACSC, from 8,220 to 10,393 , which represents a greater increase than for the whole period (20\%); but then a decrease of $5 \%$ was observed up to 2012 (9,835 hospitalizations). The variation in the rate was $+23 \%$, increasing from 64.2 in 2008 to 79 per 10,000 inhabitants in 2012.

The five groups of more frequent causes of hospitalizations for ACSC in the municipality were (in descending order): Cardiac failure (11.8\%), cerebrovascular disease $(10.6 \%)$, angina $(9.7 \%)$, bacterial pneumonia $(9 \%)$, and kidney and urinary tract infections (8.2\%) (Table 1).

Table 1 - Number, proportion and percentage variation of hospitalizations for ACSC, according to the cause group, of Guarulhos residents, from 2008 and 2012

\begin{tabular}{|c|c|c|c|c|c|c|c|c|c|c|c|c|c|}
\hline \multirow{2}{*}{ Groups of ACSC } & \multicolumn{2}{|c|}{2008} & \multicolumn{2}{|c|}{2009} & \multicolumn{2}{|c|}{2010} & \multicolumn{2}{|c|}{2011} & \multicolumn{2}{|c|}{2012} & \multicolumn{2}{|c|}{ Total } & \multirow{2}{*}{$\begin{array}{l}\text { Variation \% } \\
2012-2008\end{array}$} \\
\hline & N. & $\%$ & N. & $\%$ & N. & $\%$ & N. & $\%$ & N. & $\%$ & N. & $\%$ & \\
\hline $\begin{array}{l}\text { 1. Immunization-preventable disease and } \\
\text { sensitive conditions }\end{array}$ & 39 & 0.5 & 67 & 0.7 & 75 & 0.7 & 111 & 1.2 & 124 & 1.3 & 416 & 0.9 & $218 \%$ \\
\hline 2. Infectious gastroenteritis and complications & 390 & 4.7 & 470 & 4.8 & 519 & 5.0 & 451 & 4.7 & 332 & 3.4 & 2.162 & 4.5 & $-15 \%$ \\
\hline 3. Anemia & 92 & 1.1 & 104 & 1.1 & 83 & 0.8 & 98 & 1.0 & 78 & 0.8 & 455 & 1.0 & $-15 \%$ \\
\hline 4. Nutritional deficiencies & 129 & 1.6 & 133 & 1.4 & 161 & 1.5 & 115 & 1.2 & 103 & 1.0 & 641 & 1.3 & $-20 \%$ \\
\hline 5. Ear, nose, throat infections & 40 & 0.5 & 99 & 1.0 & 99 & 1.0 & 110 & 1.2 & 85 & 0.9 & 433 & 0.9 & $113 \%$ \\
\hline 6. Bacterial pneumonias & 825 & 10.0 & 962 & 9.9 & 961 & 9.2 & 849 & 8.9 & 694 & 7.1 & 4.291 & 9.0 & $-16 \%$ \\
\hline 7. Asthma & 521 & 6.3 & 492 & 5.0 & 495 & 4.8 & 442 & 4.7 & 488 & 5.0 & 2.438 & 5.1 & $-6 \%$ \\
\hline 8. Pulmonary disease & 428 & 5.2 & 555 & 5.7 & 643 & 6.2 & 622 & 6.5 & 613 & 6.2 & 2.861 & 6.0 & $43 \%$ \\
\hline 9. Hypertension & 443 & 5.4 & 455 & 4.7 & 490 & 4.7 & 468 & 4.9 & 421 & 4.3 & 2.277 & 4.8 & $-5 \%$ \\
\hline 10. Angina & 698 & 8.5 & 919 & 9.4 & 1.133 & 10.9 & 760 & 8.0 & 1.108 & 11.3 & 4.618 & 9.7 & $59 \%$ \\
\hline 11. Cardiac failure & 997 & 12.1 & 1.222 & 12.5 & 1.197 & 11.5 & 1.072 & 11.3 & 1.164 & 11.8 & 5.652 & 11.8 & $17 \%$ \\
\hline 12. Cerebro vascular disease & 776 & 9.4 & 965 & 9.9 & 1.171 & 11.3 & 1.100 & 11.6 & 1.065 & 10.8 & 5.077 & 10.6 & $37 \%$ \\
\hline 13. Diabetes mellitus & 493 & 6.0 & 539 & 5.5 & 524 & 5.0 & 515 & 5.4 & 542 & 5.5 & 2.613 & 5.5 & $10 \%$ \\
\hline 14. Epilepsy & 634 & 7.7 & 640 & 6.6 & 639 & 6.1 & 633 & 6.7 & 625 & 6.4 & 3.171 & 6.6 & $-1 \%$ \\
\hline 15. Kidney and urinary tract infections & 614 & 7.5 & 823 & 8.4 & 797 & 7.7 & 784 & 8.2 & 893 & 9.1 & 3.911 & 8.2 & $45 \%$ \\
\hline 16. Skin and subcutaneous tissues infections & 461 & 5.6 & 578 & 5.9 & 709 & 6.8 & 689 & 7.2 & 739 & 7.5 & 3.176 & 6.7 & $60 \%$ \\
\hline 17. Inflammatory pelvic organs disease & 80 & 1.0 & 94 & 1.0 & 96 & 0.9 & 108 & 1.1 & 97 & 1.0 & 475 & 1.0 & $21 \%$ \\
\hline 18. Gastrointestinal ulcer & 407 & 5.0 & 438 & 4.5 & 432 & 4.2 & 376 & 4.0 & 392 & 4.0 & 2.045 & 4.3 & $-4 \%$ \\
\hline 19. Prenatal and Birth-related disease & 153 & 1.9 & 195 & 2.0 & 169 & 1.6 & 202 & 2.1 & 272 & 2.8 & 991 & 2.1 & $78 \%$ \\
\hline Total ACSC & 8.220 & 100 & 9.750 & 100 & 10.393 & 100 & 9.505 & 100 & 9.835 & 100 & 47.703 & 100 & $20 \%$ \\
\hline
\end{tabular}

Source: SIH-SUS.

It was seen that the majority of diagnoses had an increase in the percentage variation (Table 1). Immunizationpreventable diseases and sensitive conditions (Group 1) had a greater rise throughout the years (218\%), followed by ear, nose, and throat infections (Group 5) (113\%) and prenatal and birth-related diseases (Group 19). As for percentage decreases, eight groups of hospitalizations for ACSC had a decrease, and the three main groups were: Group 4 (Nutritional deficiencies, 20\%), Group 6 (Bacterial pneumonia, 16\%) and Group 2 (Infectious gastroenteritis and complications).

After a breakdown of the total of hospitalizations for ACSC by gender, it was seen that males had a greater number of hospitalizations $(24,243)$, but with little difference compared to females $(23,460)$ (Table 2$)$.

It was also observed that hospitalizations for ACSC are proportionally more frequent in younger and older people, that is, children and the elderly are the most affected by avoidable hospitalizations, for both genders. As shown in Table 2, people who are 65 or older represent more than a quarter of hospitalizations for ACSC (29.9\%), and the main causes are: cardiac failure $(20.3 \%)$, cerebrovascular disease (17.9\%), and angina (10.8\%), both for male and female elderly people.

Table 2 - Number, proportion and percentage variation of hospitalizations for ACSC, by age group and gender of Guarulhos residents, from 2008 and 2012

\begin{tabular}{lcccccc}
\hline Gender & \multicolumn{2}{c}{ Female } & \multicolumn{2}{c}{ Male } & \multicolumn{2}{c}{ Total } \\
\hline Group Age(yrs) & ACSC & $\mathbf{\%}$ & ACSC & $\mathbf{\%}$ & ACSC & $\mathbf{\%}$ \\
\hline$<1$ & 1.889 & 8.1 & 2.398 & 9.9 & 4.287 & 9 \\
1 a 4 & 1.702 & 7.3 & 1.953 & 8.1 & 3.655 & 7.7 \\
5 a 14 & 1.500 & 6.4 & 1.490 & 6.1 & 2.990 & 6.3 \\
15 a 24 & 1.662 & 7.1 & 689 & 2.8 & 2.351 & 4.9 \\
25 a 34 & 1.712 & 7.3 & 1.105 & 4.6 & 2.817 & 5.9 \\
35 a 44 & 1.832 & 7.8 & 1.854 & 7.6 & 3.686 & 7.7 \\
45 a 54 & 2.630 & 11.2 & 3.542 & 14.6 & 6.172 & 12.9 \\
55 a 64 & 3.060 & 13 & 4.419 & 18.2 & 7.479 & 15.7 \\
65 e + & 7.473 & 31.9 & 6.793 & 28 & 14.266 & 29.9 \\
\hline Total & $\mathbf{2 3 . 4 6 0}$ & $\mathbf{1 0 0}$ & $\mathbf{2 4 . 2 4 3}$ & $\mathbf{1 0 0}$ & $\mathbf{4 7 . 7 0 3}$ & $\mathbf{1 0 0}$ \\
\hline
\end{tabular}

Source: SIH-SUS 
Individuals between 45 and 64 years old also had a considerable number of hospitalizations for ACSC in Guarulhos, representing $28.6 \%$ (13,651 hospitalizations). In this age group, the main avoidable diagnoses that resulted in hospitalizations were similar to the older age group, but in reverse: angina (19.9\%), cardiac failure (15.9\%) and cerebrovascular disease (15.2\%).

As for children, hospitalizations occurred mainly with children under four, for both genders, with $16.7 \%$ of hospitalizations $(7,942)$. In this age group, boys accounted for $18 \%$ of avoidable hospitalizations, whereas girls accounted for $15.4 \%$. Asthma was the main cause for these hospitalizations $(20.3 \%)$, followed by pulmonary disease (20.2\%) and bacterial pneumonia (17.2\%).

The age group with the lowest percentage of hospitalizations for ACSC was $15-24$ years old (4.9\% of total hospitalizations), and the most frequent diagnoses were: kidney and urinary tract infections (21.1\%), epilepsy $(9.7 \%)$ and skin and subcutaneous tissues infections (9.5\%), except for Group 19, which is exclusive for women and represented the main cause among them (30.8\%).

When considering only men, five main causes were identified: angina (11.9\%), cardiac failure (11.8\%), cerebrovascular disease (11\%), bacterial pneumonia (9.6\%), and skin and subcutaneous tissue infections (7.5\%). As for women, the five main causes were: cardiac failure $(11.9 \%)$, kidney and urinary tract infections $(10.7 \%)$, cerebrovascular disease $(10.3 \%)$, bacterial pneumonia $(8.4 \%)$ and epilepsy (7.5\%).

It is important to highlight that the two biggest differences between men and women concerning hospitalizations for ACSC occurred in Group 1 (for males) and in Group 3 (for females), whereas Groups 11, 4 and 2 were closer for both.

\section{DISCUSSION}

The annual fluctuation of population coverage by the FHS in Guarulhos, with the prevalence of percentage decreases, shows the difficulty of expanding the strategy in large urban centers ${ }^{(22)}$. However, the care resources of PHC do not show lack of care for the population; nevertheless, as was also identified in the State of São Paulo(23), poor coverage can be understood as the result of the way public health was developed, with a variety of traditional UBS based in large centers before the start of the FHS, which goes against small administrative divisions.

According to national literature, there is an inverse association between the number of hospitalizations for ACSC and population coverage by PHC/FHS (11-12), as in Guarulhos, where there was an increase of hospitalizations for ACSC in 2010 as well as a decrease in population coverage by the FHS, with a similar pattern in other years.
Even with the adoption by the Municipal Health Secretariat of integration of services in care networks as a priority in the restructuring of the municipal health care system, the managers admit that one of the biggest difficulties in this change concerns the continuity of care through control and coordination of the interdependencies (primary, secondary and tertiary care), as well as the absence of effective instruments to help trigger changes, such as computerization of health care records, quality of human resources, support systems, logistics, transport, and governance, among others ${ }^{(4)}$.

After research on hospitalizations for ACSC in Guarulhos, indirect evaluation of the access, effectiveness and quality of basic care ${ }^{(8,17)}$ was attempted. The increase in hospitalization rates for ACSC in the municipality (23\%) corroborates the results of a study carried out in Juiz de Fora, State of Minas Gerais ${ }^{(14)}$, but stands out from most similar publications that pointed out decreases of these rates in different regions ${ }^{(8-9,911-12)}$. This increase is possibly related to the low influence of the organization of the ambulatory system on hospitalizations. However, this interpretation cannot be extended beyond a quality check of primary health care and its accessibility, once there are other factors also associated with the results, such as: the suitability of professionals, considered as a challenge in Guarulhos, especially the permanence of doctors; the association with social, economic, political and environmental determinants; the qualification of human resources, the employment relationships and other aspects of the structural dimension ${ }^{(9,12)}$.

The most frequent causes of hospitalizations for ACSC in Guarulhos -- cardiac failure, cerebrovascular disease and angina -- are similar to other results in the country ${ }^{(9,12,14)}$. It is worth highlighting the difficulty comparing results with international studies, as they use different lists of ACSC; however, the diagnoses given are in line with foreign studies ${ }^{(10,15)}$.

Regarding the increase of the percentage variation between the groups of hospitalizations for ACSC, there is a surprising rise of $218 \%$ for immunization-preventable diseases and sensitive conditions (Group 1), with pulmonary tuberculosis (PTB) being the main cause (60\%). This is in accordance with a study carried out in Campo Grande, State of Mato Grosso do Sul(11). Guarulhos recommends the active search for respiratory symptoms, on a monthly basis, in all households covered by health community agents, supervised by FHS nurses. However, tuberculosis is known to be strongly dependent on the individual's socioeconomic and environmental conditions and its incidence may be related to the evolution of family health ${ }^{(11)}$. Therefore, the increase in the number of cases of TB is related to the poor results of social indicators and the large vulnerable areas found in the municipality.

It is worth highlighting that nearly half the population $(48.3 \%)$ of Guarulhos is living in conditions rated 
as medium, high or very high social vulnerability, described in the last report of the Social Vulnerability Index from São Paulo in 2010 (http://www.iprsipvs.seade. gov.br). This reality determines the health conditions in society in general.

Ear, nose, throat infections (Group 5), despite having the second largest increase over the years studied (113\%), had little relevance when analyzed in the general total of hospitalizations for ACSC (less than 1\%). However, it is important to note that these infections are associated with the excess of pollutants that degrade the quality of air, like ozone, which is responsible for airway irritation and the decrease of lung capacity. According to the Environmental Company of São Paulo (CETESB) ${ }^{(24)}$, the metropolitan region of the state has been suffering from excessive emission of particles into the environment, which further explains the airway infections.

Likewise, prenatal and birth-related diseases also showed a significant rise over the years (78\%) and was low percentage when compared to the total of hospitalizations for ACSC (2.1\%) during the period, which was found in similar research ${ }^{(11,17)}$. This group is generally associated with the proportion of pregnant women who had seven or more prenatal consultations (there was a $6 \%$ increase of this indicator in Guarulhos), but it was noticed that the number of consultations does not ensure the quality of care ${ }^{(25)}$. Therefore, this percentage rise can be the result of the mothers' low education levels ${ }^{(26)}$, as well as the low family incomes, which is an evident fact seen in social evaluations of the city and is essential for the individual's health.

As for nutritional deficiencies and anemia, which had a percentage decrease over the five years studied, they occurred in more than $50 \%$ of elderly women over 65 years old. Despite the ease of identifying and treating these diseases through basic care, elderly people usually rely on other people/relatives for personal care, and the majority of these caregivers work during the open hours of UBS, which makes it difficult to have access to complete care for typical diseases of advanced age ${ }^{(13)}$.

The group of bacterial pneumonia, which showed the second largest decrease in the period (16\%), concerns pneumonia that was not specified. Despite the downward curve, this group represents the fifth sensitive condition in the municipality, which justifies its understanding, as shown in a study that established the profile of hospitalizations for ACSC related to smoking, and an association with heart and respiratory disease was found, especially in elderly people ${ }^{(27)}$. Thus, we see that these infections strongly depend on social and behavioral conditions to which the individuals are exposed.

The data also show, among elderly people, the occurrence of hospitalizations for ACSC, especially for chronic diseases (cardiac failure, cerebrovascular disease and angina), both for men and women. The results are similar for people who are 45 years old and over. The prevalence of chronic noncommunicable diseases is determined by urbanization and the consequent demographic transition, as well as by the increase in life expectancy, illness due to advanced age and a decrease of fertility rate $e^{(4)}$, which are factors largely seen in the municipality of Guarulhos over the years ${ }^{(21)}$.

Regarding children under four years old, the younger they are, the higher the rates of hospitalizations for ACSC, which are mainly caused by respiratory tract diseases (asthma, pulmonary disease and bacterial pneumonia) and infectious gastroenteritis and complications. This fact is in line with other studies ${ }^{(14,17)}$. Concerning the low incidence of hospitalizations for ACSC among young people between 15 and 24 years old, this must be interpreted taking into account the social and vulnerability factors that affect this age group, such as the early insertion in the labor market and exploitation, the difficulty of access to school and health services, violence, use of drugs, illtreatment, and social exclusion, among others ${ }^{(28)}$.

The interpretation of hospitalizations for ACSC compared between genders shows that men were hospitalized more frequently for pulmonary tuberculosis, gastrointestinal ulcers and angina, diseases related to habits, inadequate nutrition and lack of control of risk factors and aspects determined by the current way of life. On the other hand, women were hospitalized more frequently for anemia, kidney and urinary tract infections and epilepsy, which are diseases that are easily identified by primary care and patients are immediately referred to hospitals after diagnosis.

It is important to remember that this research led to a greater understanding of the picture of hospitalizations for ACSC occurring in Guarulhos; however, the quality of results obtained from the SIH-SUS database does not always match the reality and can affect the assessment of the local effectiveness of primary health care ${ }^{(29)}$.

\section{CONCLUSION}

The increase in the rate of hospitalizations for ACSC in Guarulhos proves the fragility of ambulatory systems, especially primary care, which cannot meet the needs and demands of people, despite being the gateway for treating the main illnesses that affect the population. In addition, we can see that even though Guarulhos is a wealthy municipality, local people still suffer from essential aspects that determine the nature of illness, such as social, economic, and environmental vulnerabilities, among others.

The overcoming of fragmented care, considered to be a major challenge for the city, can be achieved with investments in the health care network, especially if they are 
oriented toward the management of chronic conditions and based on demographic and epidemiological transition, and mainly, if they integrate biological events with social matters in order to effectively change the territorial situation.

This research, despite having limitations that are associated with the ecological method, which cannot represent the individual, raises awareness among health professionals, students and managers concerning reflections on the primary care infrastructure in different spaces throughout Brazil, and points out that the need to expand the FHS is not the only reason for improving the access to health services and people's health conditions. In Guarulhos, hospitalizations for ACSC reveal a little about the way PHC works in the municipality, but it is necessary to go further in the social determinants of the many health problems that directly affect the quality and effectiveness of primary care.

\section{REFERENCES}

1. Vaitsman J, Ribeiro JM, Lobato LVC. Análise de políticas, políticas de saúde e a saúde coletiva. Physis Rev Saúde Coletiva [Internet]. 2013 [citado 2014 mar. 10];23(2):589-611. Disponível em: http:// www.scielo.br/pdf/physis/v23n2/v23n2a14.pdf

2. Egry EY, Fonseca RMGS, Oliveira MAC. Ciência, Saúde Coletiva e Enfermagem: destacando as categorias gênero e geração na episteme da práxis. Rev Bras Enferm. [Internet]. 2013 [citado 2014 mar. 05];66(n.esp):119-33. Disponível em: http://www. scielo.br/pdf/reben/v66nspe/v66nspea16.pdf

3. Mello GA, Fontanella BJB, Demarzo MMP. Atenção Básica e Atenção Primária à Saúde: origens e diferenças conceituais. Rev APS [Internet]. 2009 [citado 2013 fev. 15];12(2):204-213. Disponível em: http://aps.ufjf.emnuvens.com.br/aps/article/view/307

4. Mendes EV. As Redes de Atenção à Saúde. Brasília: OPAS; 2011.

5. Silva JA. Um estudo da Atenção Primária à Saúde mediante o indicador: Internações por Condições Sensíveis à Atenção Ambulatorial (CSAA) [tese doutorado]. Rio de Janeiro: Instituto de Medicina Social, Centro Biomédico, Universidade do Estado do Rio de Janeiro; 2011.

6. Brasil. Ministério da Saúde; Secretaria de Atenção à Saúde, Departamento de Atenção Básica. Política Nacional de Atenção Básica (PNAB). Brasília; 2012.

7. Brasil. Ministério da Saúde. Sala de apoio à Gestão Estratégica do Ministério da Saúde (SAGE) [Internet]. Brasília; 2014 [citado 2014 mar. 10]. Disponível em: http://189.28.128.178/sage/

8. Alfradique ME, Bonolo PF, Dourado I, Lima-Costa MF, Macinko J, Mendonça SC, et al. Internações por condições sensíveis à atenção primária: a construção da lista brasileira como ferramenta para medir o desempenho do sistema de saúde (Projeto ICSAP Brasil). Cad Saúde Pública [Internet]. 2009 [citado 2014 jan. 20];25(6):1337-49. Disponível em: http://www.scielo.br/pdf/csp/v25n6/16.pdf

9. Elias E, Magajenski F. A Atenção Primária à Saúde no sul de Santa Catarina: uma análise das internações por condições sensíveis à atenção ambulatorial, no período de 1999 a 2004. Rev Bras Epidemiol [Internet]. 2008 [citado 2013 jan. 20];11(4):633-47. Disponível em: http://www.scielosp.org/ pdf/rbepid/v11n4/10.pdf
10. Ansari Z, Haider SI, Ansari H, Gooyer T, Sindall C. Patient characteristics associated with hospitalizations for ambulatory care sensitive conditions in Victoria, Australia. BMC Health Serv Res. 2012;12:475.

11. Campos AZ, Theme-Filha MM. Internações por condições sensíveis à atenção primária em Campo Grande, Mato Grosso do Sul, Brasil, 2000 a 2009. Cad Saúde Pública [Internet]. 2012 [citado 2014 jan. 19];28(5)845-55. Disponível em: http://www.scielo.br/pdf/csp/v28n5/04.pdf

12. Pazó RG, Frauches DO, Galvêas DP, Stefenoni AV, Cavalcante ELB, Pereira-Silva FH. Internações por condições sensíveis à atenção primária no Espírito Santo: estudo ecológico descritivo no período 2005-2009. Epidemiol Serv Saúde [Internet]. 2012 [citado 2014 fev. 10];21(2):275-82. Disponível em: http://scielo.iec.pa.gov.br/pdf/ess/v21n2/v21n2a10.pdf

13. Rehem TCMSB, Oliveira MRF, Amaral TCL, Ciosak SI, Egry EY. Hospitalisations for ambulatory care sensitive conditions in a Brazilian metropolis. Rev Esc Enferm USP [Internet]. 2013 [cited 2014 Feb 20];47(4):884-90. Available from: http://www.scielo.br/pdf/reeusp/v47n4/en_0080-6234reeusp-47-4-0884.pdf

14. Rodrigues-Bastos RM, Campos EMS, Ribeiro LC, Firmino RUR, Bustamante-Teixeira MT. Internações por condições sensíveis à atenção primária em município do sudeste do Brasil. Rev Assoc Med Bras [Internet]. 2013 [citado 2014 fev. 20];59(2):120-7. Disponível em: http://www.scielo.br/pdf/ ramb/v59n2/v59n2a10.pdf

15. Roos LL, Walld R, Uhanova J, Bond R. Physician visits, hospitalizations and socioeconomic status: ambulatory care sensitive conditions in a Canadian setting. Health Serv Res. 2005;40(4):1167-85.

16. Brasil. Ministério da Saúde. Portaria n. 221, de 17 de abril de 2008. Publica em forma do anexo a Lista Brasileira de Internações por Condições Sensíveis à Atenção Primária [Internet]. Brasília; 2008 [citado 2014 fev. 20]. Disponível em:http://dtr2001.saude.gov.br/sas/PORTARIAS/Port2008/ PT-221.htm 
17. Rehem TCMSB. Internações sensíveis à atenção primária: limites e possibilidades da lista brasileira de diagnósticos [tese doutorado]. São Paulo: Escola de Enfermagem, Universidade de São Paulo; 2011.

18. Guarulhos. Secretaria Municipal de Saúde. Plano Municipal de Saúde 2010/2013. [Internet]. Guarulhos; 2010 [citado 2013 jan. 10]. Disponível em: http://www.guarulhos.sp.gov. br/files/plano_m_saude_2010_2013_final_julho-11.pdf

19. Egry EY. Saúde coletiva: construindo um novo método em enfermagem. São Paulo: Ícone; 1996.

20. Instituto Brasileiro de Geografia e Estatística. IBGE Cidades. Guarulhos, SP [Internet]. Rio de Janeiro; 2013 [citado 2014 jan. 23]. Disponível em: http://www.cidades.ibge.gov.br

21. Nações Unidas. Programa das Nações Unidas para o Desenvolvimento (PNUD). Atlas do Desenvolvimento Humano no Brasil. Perfil Municipal, Guarulhos, SP [Internet]. 2013 [citado 2014 jan 25]. Disponível em: http://atlasbrasil.org. br/2013/pt/perfil/guarulhos_sp

22. Conill EM. Ensaio histórico-conceitual sobre a Atenção Primária à Saúde: desafios para a organização de serviços básicos e da Estratégia Saúde da Família em centros urbanos no Brasil. Cad Saúde Pública [Internet]. 2008 [citado 2014 jan 15];24 Supl.1:S7-S16. Disponível em: http://www.scielo. $\mathrm{br} / \mathrm{pdf} / \mathrm{csp} / \mathrm{v} 24 \mathrm{~s} 1 / 02 . \mathrm{pdf}$

23. Sala A, Mendes JDV. Perfil de Indicadores da Atenção Primária à Saúde no Estado de São Paulo: retrospectiva de 10 anos. Saúde Soc [Internet]. 2011 [citado 2014 mar. 02];20(4):912-26. Disponível em: http://www.scielo.br/pdf/ sausoc/v20n4/09.pdf
24. Companhia Ambiental do Estado de São Paulo (CETESB). Relatório de qualidade do ar no Estado de São Paulo [Internet]. 2012 [citado 2014 mar. 10]. Disponível em: http:// www.cetesb.sp.gov.br/ar/qualidade-do-ar/31-publicacoese-relatorios

25. Silveira DS, Santos IS, Costa JSD. Atenção pré-natal na rede básica: uma avaliação da estrutura e do processo. Cad Saúde Pública [Internet]. 2001 [citado 2014 fev. 10];17(1):131-9. Disponível em: http://www.scielo.br/pdf/csp/v17n1/4068.pdf

26. Vettore M, Lamarca G. Atenção pré-natal no Brasil: uma questão de oferta, de acesso ou de escolaridade materna? In: Determinantes Sociais da Saúde. Portal e Observatório sobre Iniquidades em Saúde [Internet]. 2012 [citado 2014 mar. 05]. Disponível em: http://dssbr.org/site/2012/05/ atencao-pre-natal-no-brasil-uma-questao-de-oferta-deacesso-ou-de-escolaridade-materna/

27. Portes LH, Silva JA, Bustamante-Teixeira MT, Ribeiro LC. Internações por condições sensíveis à atenção ambulatorial tabaco-relacionadas: perfil de um município de grande porte. J Manag Prim Health Care [Internet]. 2013 [citado 2014 mar. 12];4(2):84-101. Disponível em: http://jmphc. com/ojs/index.php/01/article/viewArticle/102

28. Pessalacia JDR, Menezes ES, Massuia D. A vulnerabilidade do adolescente numa perspectiva das políticas de saúde pública. Rev Bioethikos [Internet]. 2010 [citado 2014 mar. 07];4(4):423-30. Disponível em: http://www.saocamilo-sp. $\mathrm{br} / \mathrm{pdf}$ /Bioethikos_423-430_.pdf

29. Rehem TCMSB, Oliveira MRF, Ciosak SI, Egry EY. Record of hospitalizations for ambulatory care sensitive conditions: validation of the hospital information system. Rev Latino Am Enferm [Internet]. 2013 [cited 2014 Feb 20];21(5):1159-64. Available from: http://www.scielo.br/pdf/rlae/v21n5/01041169-rlae-21-05-1159.pdf 